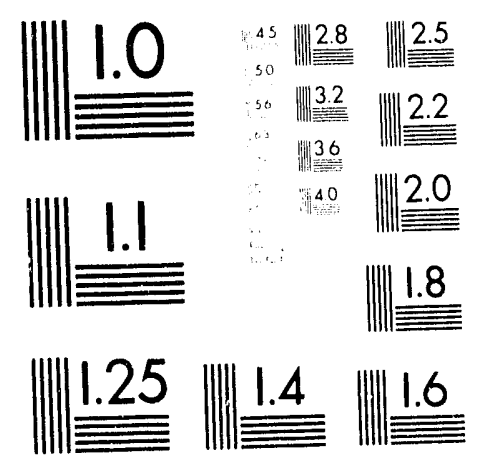



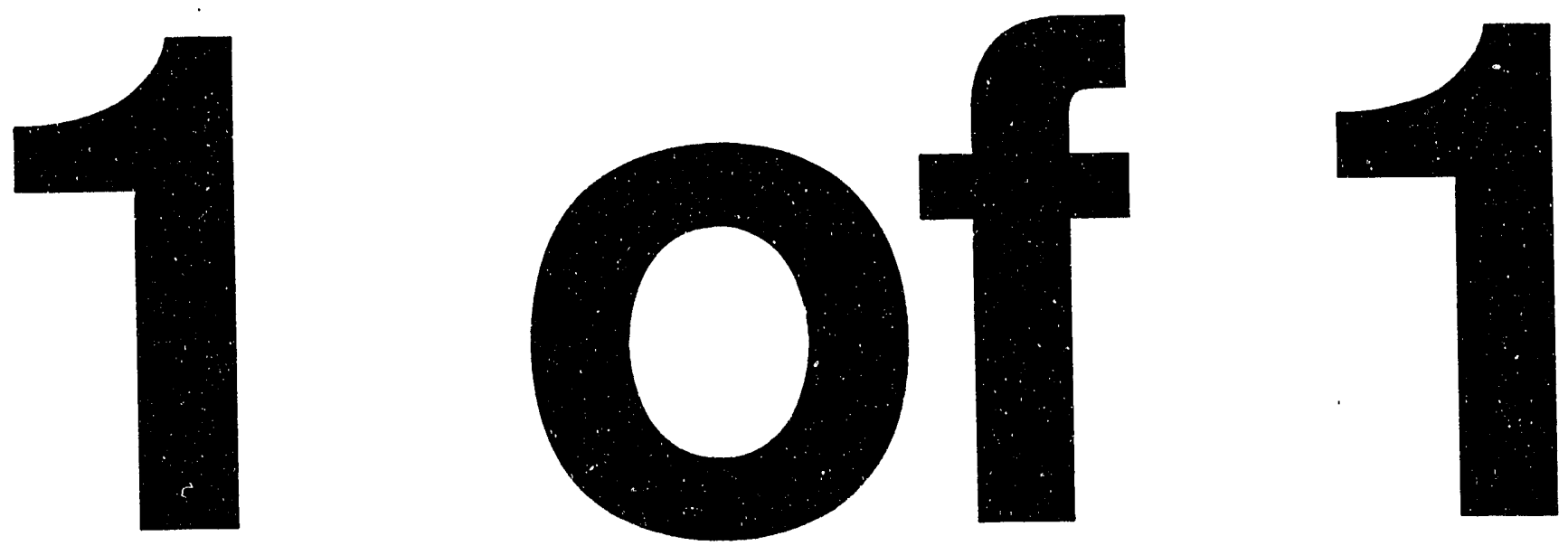


\title{
Treatment of Produced Waters by Electrocoagulation and Reverse Osmosis
}

\section{Topical Report}

\author{
K. Tuggle \\ M. Humenick \\ F. Barker
}

August 1992

Work Performed Under Contract No.: DE-FC21-86MC11076

For

U.S. Department of Energy

Office of Fossil Energy

Morgantown Energy Technology Center

Morgantown, West Virginia

By

University of Wyoming Westem Research Institute Laramie, Wyoming 


\section{DISCLAIMER}

This report was prepared as an account of work sponsored by an agency of the United States Government. Neither the United States Government nor any agency thereof, nor any of their employees, makes any warranty, express or implied, or assumes any legal liability or responsibility for the accuracy, completeness, or usefulness of any information, apparatus, product, or process disclosed, or represents that its use would not infringe privately owned rights. Reference herein to any specific commercial product, process, or service by trade name, trademark, manufacturer, or otherwise does not necessarily constitute or imply its endorsement, recommendation, or favoring by the United States Government or any agency thereof. The views and opinions of authors expressed herein do not necessarily state or reflect those of the United States Government or any agency thereof.

This report has been reproduced directly from the best available copy.

Available to DOE and DOE contractors from the Office of Scientific and Technical Information, P.O. Box 62, Oak Ridge, TN 37831; prices available at (615) 576-8401.

Available to the public from the National Technical Information Service, U.S. Department of Commerce, 5285 Port Royal Rd., Springfield, VA 22161; phone orders accepted at (703) 487-4650. 
Treatment of Produced Waters by Electrocoagulation and Reverse Osmosis

Topical Report

K. Tuggle

M. Humenick

F. Barker

Work Performed Under Contract No.: DE-FC21-86MC11076

For

U.S. Department of Energy

Office of Fossil Energy

Morgantown Energy Technology Center

P.O. Box 880

Morgantown, West Virginia 26507-0880

By

University of Wyoming

Western Research Institute

P. O. Box 3395

Laramie, Wyoming 82071

August 1992 


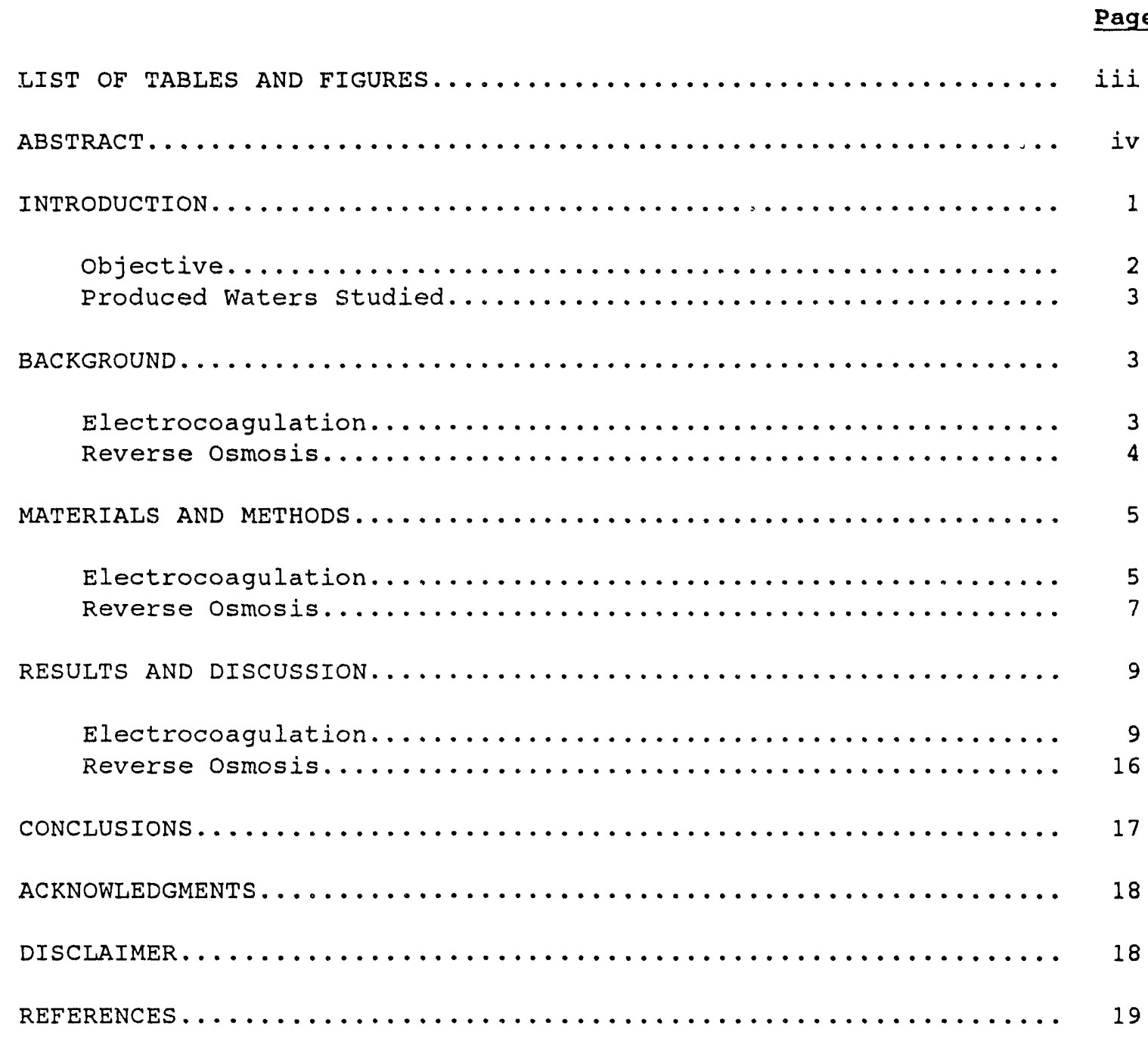




\section{LIST OF TABLES AND FIGURES}

\section{Table}

1. National Pollutant Discharge Elimination system Permit Limitations........................... 2

2. Operating Conditions for Electrocoagulation Treatment...... 8

3. Characterization of Untreated Produced Waters........... 10

4. Results of Electrocoagulation Treatment on Low Radium Oil

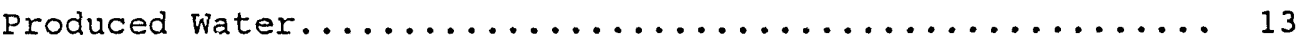

5. Results of Electrocoagulation Treatment on Coal Bed Methane Produced water............................. 14

6. Results of Electrocoagulation Treatment on High Radium Oil

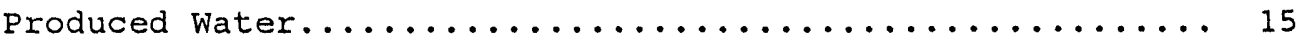

7. Results of Reverse Osmosis Treatment on Coal Bed Methane

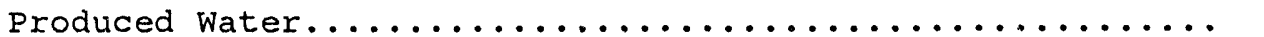

1. Properties of Membrane Materials.................. 5

2. Electrocoagulation Unit....................... 6 


\section{ABSTRACT}

Two oil field produced waters and one coal bed methane produced water from wyoming were treated with electrocoagulation and reverse osmosis. All three produced waters would require treatment to meet the new Wyoming Department of Environmental quality requirements for effluent discharge into a class III or IV stream. The removal of radium 226 and oil and grease was the primary focus of the study.

Radium 226 and $0 i 1$ and grease were removed from the produced waters with electrocoagulation. The best removal of radium 226 ( $>848$ ) was achieved with use of a non-sacrificial anode (titanium). The best removal of oil and grease (>938) was achieved using a sacrificial anode (aluminum). By comparison, reverse osmosis removed up to 878 of the total dissolved solids and up to $95 \%$ of the radium 226 . 


\section{INTRODUCTION}

The extraction of oil and gas from subterranean formations also produces an aqueous stream that must be disposed of or put to beneficial use. In wyoming this aqueous stream may be highly saline and may contain dissolved hydrogen sulfide, residual hydrocarbons, turbidity, dissolved radium, or other undesirable components. The oil and gas industry in Wyoming produces a large amount of water that could be put to beneficial use if properly treated. The volume of water produced in Wyoming through oil and gas extraction in 1988 was 1.729 billion barrels or 73 billion gallons. The liberation of methane from a coal-bearing formation also requires the extraction of large volumes of grourdwater in order to lower the hydrostatic pressure in the formation. The quality of coal bed methane produced water ranges from near drinking water quality to toxic wastewaters with salinity higher than sea water (U.S. Department of the Interior 1990).

All oil and gas produced waters in wyoming must meet requirements established by the Wyoming Department of Environmental Quality (WDEQ) to be discharged into a receiving body of water or onto the land surface. separate regulations exist for the type of receiving water or land surface receiving the discharge, whether it be a cold water fishery, a groundwater aquifer, or a dry gulch. Produced waters that exceed the established limit for a given parameter must be treated until the level of that component is brought below the limit, or the water cannot be discharged. An alternative, and most common, disposal method for produced water is to reinject the water into a subterranean formation that has poor quality water ( $>10,000 \mathrm{mg} / \mathrm{L}$ total dissolved solids). However, reinjection is expensive and treatment of the produced waters for discharge may often be less costly and could produce an aqueous stream that has beneficial uses. The treated produced water could be used for livestock watering, agriculture, game and fish propagation, tertiary recovery, and boiler/heat exchanger feed. Many parts of wyoming have water shortages and would benefit from the use of a discharged produced water of acceptable quality. The current limitations for discharge of a produced water into a class III or IV stream are shown in Table 1. A class III stream is defined by the WDEQ as any surface water that supports, or has the potential to support nongame fish. A class IV stream is defined as a surface water that does not have the hydrologic or natural water quality potential to support fish (WDEQ 1984).

The toxicity of a discharge is currently determined by the wyoming whole effluent toxicity program. An acute toxicity test is run on the discharge. In this test fathead minnows and a small crustacean (Ceriodaphnea dubia) are exposed to 1008 effluent for a period of 96 and 48 hours, respectively. If greater than $20 \%$ mortality occurs during the exposure period, the discharge is considered toxic (Cox 1989). 
Table 1. National pollutant Discharge Elimination system Permit Limitations

Parameter

Value

TDS

Oil \& Grease

$\mathrm{pH}$

Radium 226

Chlorides

sulfates

Toxic substances
$5000 \mathrm{mg} / \mathrm{L}$

$10 \mathrm{mg} / \mathrm{L}$

6.5-8.5

$60 \mathrm{pc} / \mathrm{L}$

$2000 \mathrm{mg} / \mathrm{L}$

$3000 \mathrm{mg} / \mathrm{L}$

Concentrations below

levels toxic to aquatic life

\section{Objective}

The principal objective of this study was to evaluate electrocoagulation and reverse osmosis as water treatment technologies designed to upgrade produced water for beneficial use as opposed to reinjecting the water into the oil-bearing strata. Three produced waters were obtained and evaluated. Two waters were associated with oil production; the other water resulted from coal bed methane production. In the case of the water samples from oil production, the oil companies will be required to further treat this produced water to meet new discharge requirements for radium and other toxic compounds. The water was characterized before and after treatment to establish the change in the physical-chemical properties of the water induced by the treatment process.

Conventional water treatment methods have been proven successful for the treatment of produced waters, but such treatment is often not economically feasible. In this study, the use of electrocoagulation as an alternative treatment method was investigated. The use of electrocoagulation as a water treatment technology has not been thoroughly studied in the reference literature since its conception; however, with the current increase in environmental regulation it may be a feasible alternative to conventional treatment systems.

In the electrocoagulation prosess, the aqueous stream is passed through a region of electric potential, thereby initiating physicalchemical reactions. The precipitate or "floc" that is formed settles out of the water and is separated and disposed of, thus altering the physical-chemical properties of the water.

The use of reverse osmosis as a treatment alternative for produced water was also jnvestigated. The results of the reverse osmosis treatment process are compared with the results of the electrocoagulation treatment process with consideration given to economic feasibility of the processes and the intended use of the discharged produced water. 


\section{Produced Waters studied}

Three produced waters were located that contained the specific qualities outlined below. In each case, samples were collected and contained according to the sampling procedures outlined in 1990 U.S. Environmental protection Agency (EPA) Standard Methods for the specific analysis performed.

The initial step was to find an oil-produced water that was currently being discharged and had radium 226 levels near or above the current WDEQ discharge limit of $60 \mathrm{pc} / \mathrm{L}$ into a class III or IV stream. With information supplied by the wyoming Oil and Gas commission and WDEQ, a suitable produced water sample was obtained from an oil producer in central wyoming. Samples were taken at the EPA sampling point from the discharged aqueous stream and then transported back to western Research Institute (WRI) for characterization. The EPA sampling point is downstream from an oil and water separating system that employs a coagulating chemical followed by a hydrocell unit.

The second sample was also an oil produced water obtained from central wyoming. The oil producer composited waters from two separate oil-producing formations before discharging. No treatment existed upstream from the sampling point other than a gravity-aided water-oil separation tank.

The third produced water was obtained from a coal bed methane production well in southern wyoming. Samples were taken from a pond near the production well and were transported back to WRI. The produced water had been pumped directly from the production well to the pond, without pretreatment.

\section{BACKGROUND}

\section{Electrocoagulation}

Electrocoagulation is a process in which an aqueous stream containing colloidal particles and sparingly-soluble salts are coagulated when passed through an electrical field. Physical and chemical processes occurring during electrocoagulation facilitate the removal of suspended and dissolved solids within the solution.

The coagulated particles aggregate and form flocs. As the floc begins to settle, other colloidal suspended particles are entrapped or adsorbed on the floc and can also be removed from the solution.

According to classical electric double layer theory, for colloidal suspended particles to aggregate and form flocs, the attractive forces between the particles must exceed the repulsive forces. Most colloidal suspended particles in water are positively or negatively charged and they therefore will attract or repulse one another. Repulsive forces due to an electric charge are known as electric potential forces. The surface charge on the particle is usually measured in terms of zeta 
potential, which influences the electric potential forces. The electric potentjal forces decrease rapidly in magnitude as the distance from the particle increases. Electrocoagulation is believed to lower the Zeta potential on a particle by facilitating the release of ions, which will react with the surface of the charged particle. As the zeta potential decreases, the repulsive forces between particles decrease, allowing the particles to remain in closer proximity (Thortec International 1988).

All particles have an attractive force known as Van der wals forces. Van der wals forces are small in magnitude over larger distances but increase rapidly as two particles approach each other (e.g., <10 angstroms). If the zeta potential and repulsive forces of a charged particle have been weakened by the electrocoagulation process, Van der wals forces may be strong enough to aggregate particles, thereby causing a floc to form. This process would be aided by hydrodynamic and thermodynamic forces within the electrocoagulation unit which facilitate particle movement and inter-particle contact.

During electrocoagulation, trivalent metal ions are released into the solution when a sacrificial anode such as aluminum or iron is used. These trivalent ions are positively charged and will adsorb onto negatively charged colloids. Large particle masses can be formed as negatively charged particles are joined together by the metal ions and polymeric hydroxo complexes. The resulting mass of particles will tend to settle out of the solution (Renk 1988). Chemical coagulation using aluminum and iron salts results in the same mechanisms for the aggregation of colloidal particles to form heavy flocs.

Electrocoagulation chemically alters the aqueous stream by causing oxidation-reduction reactions and further reactions of modified anions and cations to form solids. These reactions are facilitated by the release of anodic material into the solution when a sacrificial anode such as iron or aluminum is used. Iron and aluminum are considered sacrificial because they release oxidized metal ions into the solution. If an inert anode such as titanium or platinum is used, oxygen is produced at the anode and may oxidize other oxidizable substances. The solids produced by this process can potentially precipitate. The floc formed by the precipitate may again entrap and/or adsorb suspended colloidal particles and other soluble species in the solution, thereby further purifying the solution.

\section{Reverse Osmosis}

Reverse osmosis (RO) and membrane filtration are common terms used for a broad range of separation processes from filtration and ultrafiltration to actual reverse osmosis (Eckenfelder 1989). Reverse osmosis employs a semipermeable membrane that will allow pure water to flow through the membrane. Dissolved and suspended solids are rejected by the membrane and will concentrate on the high pressure side of the RO unit. Because of diffusion, water tends to flow from a solution of low salinity to a solution of higher salinity. The diffusion force that drives the water through the membrane from the low salinity side to the high salinity side is known as the osmotic presslire. Pressure created by the Ro unit overcomes this osmotic pressure, thus the term, reverse 
osmosis. Ultrafiltration refers to systems where microscopic holes or pores exist in the filter media. These pores will allow molecules and ions to pass through the filter media if the molecule or particle is smaller than the pore opening.

Reverse osmosis and membrane filtration require a pressure gradiert across the membrane or filter media. This pressure will overcome the osmotic pressure, and/or resistance of the filter, and will drive water through the media. The rejected dissolved and suspendec solids are thus concentrated on the high pressure side of the Ro unit, and the purified water or permeate can be put to its intended use or be safely discharged.

There are a multitude of membrane materials available commercially. Choosing an appropriate membrane for the given application depends on the membrane's reaction to the feedwater, the required percent rejection of salts, the operating pressure of the Ro unit, the temperature and $\mathrm{pH}$ of the feedwater, plus any other parameters that may affect the performance of the specific membrane. The four most commonly used membrane materials are cellulose acetate (CA), cellulose triacetate (CTA), aromatic polyamide (PA), and polysulfone (PS). Some general properties of these membrane materials are shown in Figure 1.

\begin{tabular}{|c|c|c|c|c|c|c|c|c|}
\hline Flux & Smaller & $\mathrm{PA}$ & ---- & CTA - - - & $\mathrm{CA}-$ & ---- & PS & Larger \\
\hline Salt Rejection & Larger & PS & ---- & $\mathrm{PA}----$ & C'TA & --- & $\mathrm{CA}$ & Smaller \\
\hline \multicolumn{9}{|l|}{ Sensitivity to } \\
\hline Biological Attack & Lower & PS & ---- & $\mathrm{PA}-\cdots-$ & $\operatorname{ctA}$ & --- & $C A$ & Greater \\
\hline \multicolumn{9}{|l|}{ Sensitivity to } \\
\hline Hydrolysis & Lower & PS & ---- & $\mathrm{PA}----$ & CTA & $-\cdots$ & $\mathrm{CA}$ & Greater \\
\hline Resistance to Oxidants & Greater & PS & --- & CTA - & $\mathrm{CA}$ & ---- & $\mathrm{PA}$ & Lower \\
\hline
\end{tabular}

Figure 1. Properties of Membrane Materials

MATERIALS AND METHODS

\section{Electrocoagulation}

The electrocoagulation unit used in the study was modeled after the Liggett design with incorporation of the Herbst/Renk patent modification (Patent Application 1987). This design incorporates an inner and outer piping system with a helical wrapping to promote turbulent flow and minimize the build-up of a stationary layer of ionic particles on the charged surface (Figure 2). The feedwater enters the unit in the inner pipe, travels the length of the inner pipe until the inner pipe ends, and opens up into the outer pipe. Here the water flow reverses 


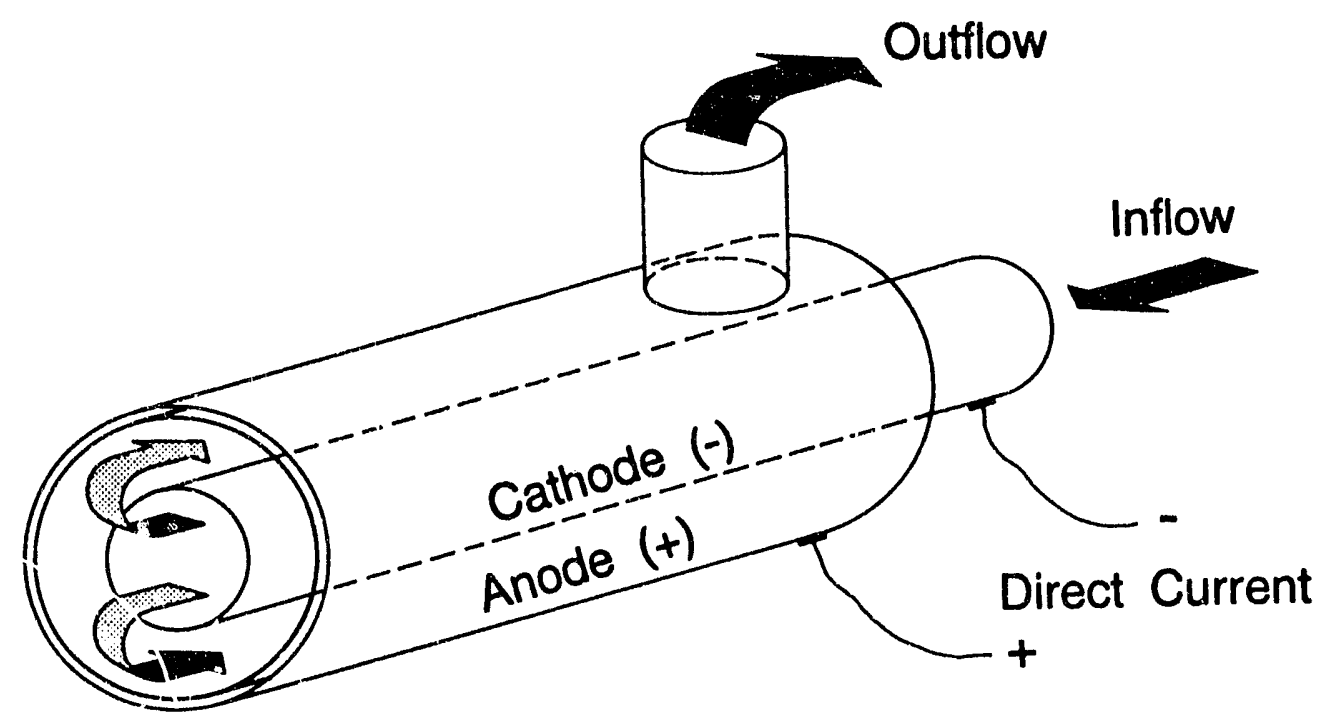

Figure 2(a). Wastewater Flow Through Electrocoagulation Unii and Polarity of the Inner and Outer Piping System

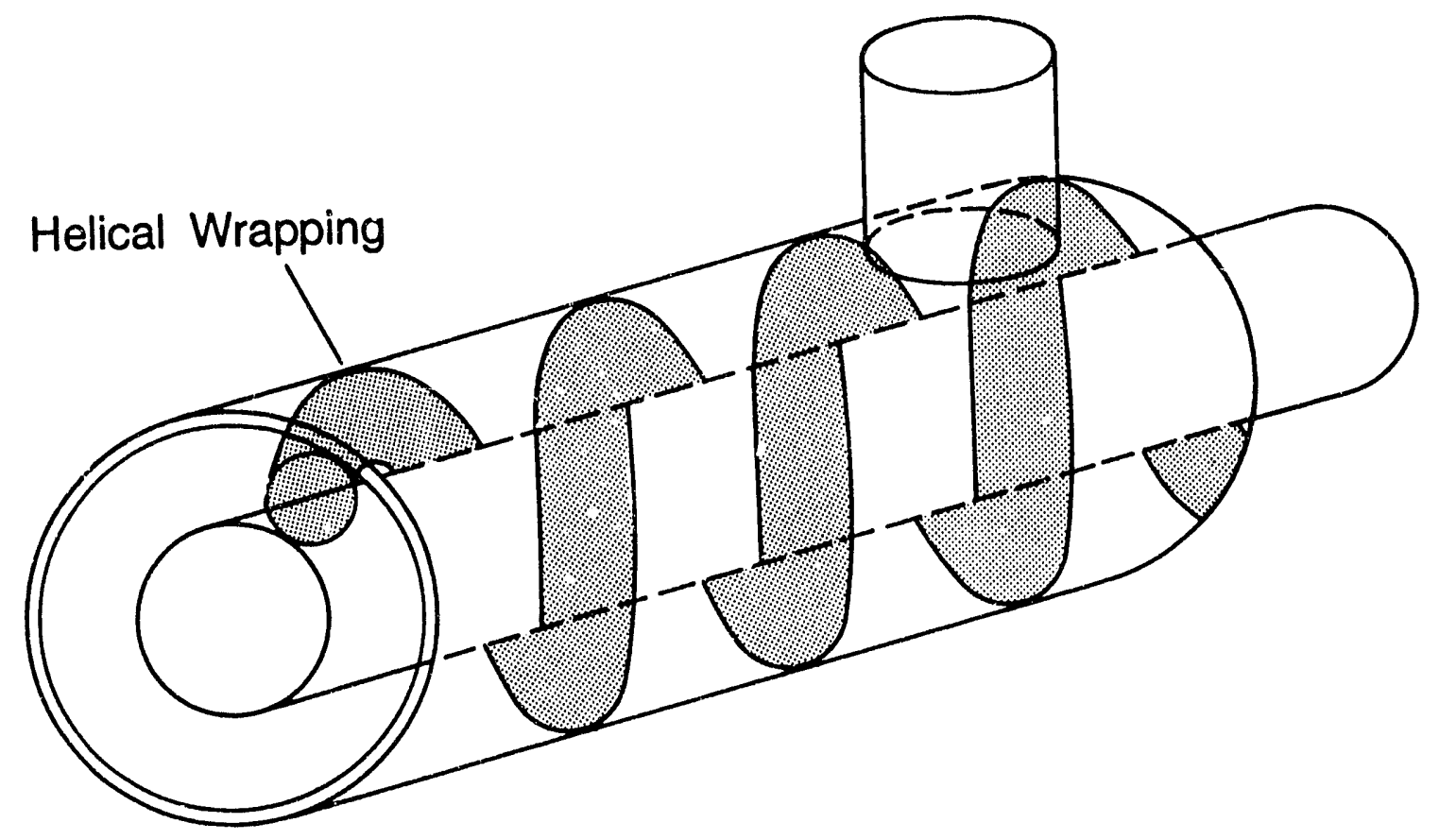

Figure 2(b). Helical Wrapping Between Inner and Outer Pipe

Figure 2. Filectrocoagulation Unit 
direction and flows between the inner and outer pipe, back to an outlet at the front of the unit where the treated water exits the unit. In the electrocoagulation unit the inner pipe acts as the cathode and the outer pipe acts as the anode. The outer pipe had a $11 / 4$-inch inside diameter and the inner pipe had a 1/2-inch inside diameter. Each pipe was approximately 24 inches long.

A Masterflex veristatic pump was connected to the electrocoagulation unit to supply the solution flow. The DC power supply was delivered by a Powerstat 100 volt voltage supply unit. Each electrocoagulation tube was cleaned with acetone before testing was conducted. Distilled water was run through the electrocoagulation unit after each run for a period of 5 minutes to clean the unit. Samples were collected in acid-washed glass containers and the overnight settling procedure was conducted in a refrigerated storage area. The energy input that the electrocoagulation unit delivered to the water was dependent on the electrolytic characteristics of the water and the type of cathode material. A constant current of 20 amps through the unit was naintained allowing voltage to vary. Energy input was not optimized in this study. See Table 2 for the electrocoagulation operating conditions.

A sample of the produced water with the highest radium 226 concentration was filtered through standard filter paper and analyzed for radium 226 to establish whether the radium 226 was associated with the soluble or insoluble fraction of the total solids. The results from the filtered sample would also indicate whether the electrocoagulation process was physically and chemically altering the produceu water stream.

\section{Reverse Osmosis}

The RO unit used in this study was the laboratory scale sepa CF-HP Membrane cell model, manufactured by osmonics. A Jaeco piston pump, model 106-115-S2T2, 1/3 hp, was used as the high pressure pumping source. The sepa CF-HP membrane cell and the Jaeco pump were designed for pressures up to 1000 and 1300 psig, respectively. A damping system was employed to dampen the pressure variation over the pump stroke of the piston pump. The damping system consisted of three gas-filled containers positioned along the pressure line from the pump to the RO unit. The pressurized feedwater flowed into the containers, thereby compressing the gas, and the feedwater exited the container somewhat dampened. With this damping system the pressure variation over the pump stroke could be reduced to approximately $50 \mathrm{psig}$.

The three membranes used in the study were all obtained from osmonics. The selection of membranes was limited to those that could withstand the chemical composition of the produced waters and the high pressures required for treatment of high salinity waters, without being damaged or physically altered. The three membranes used were the sepa SR10, the sepa ST10, and the Sepa MS10. The SR10 and ST10 membranes are cellulose acetate membranes and the MS10 is a polyamide membrane. 


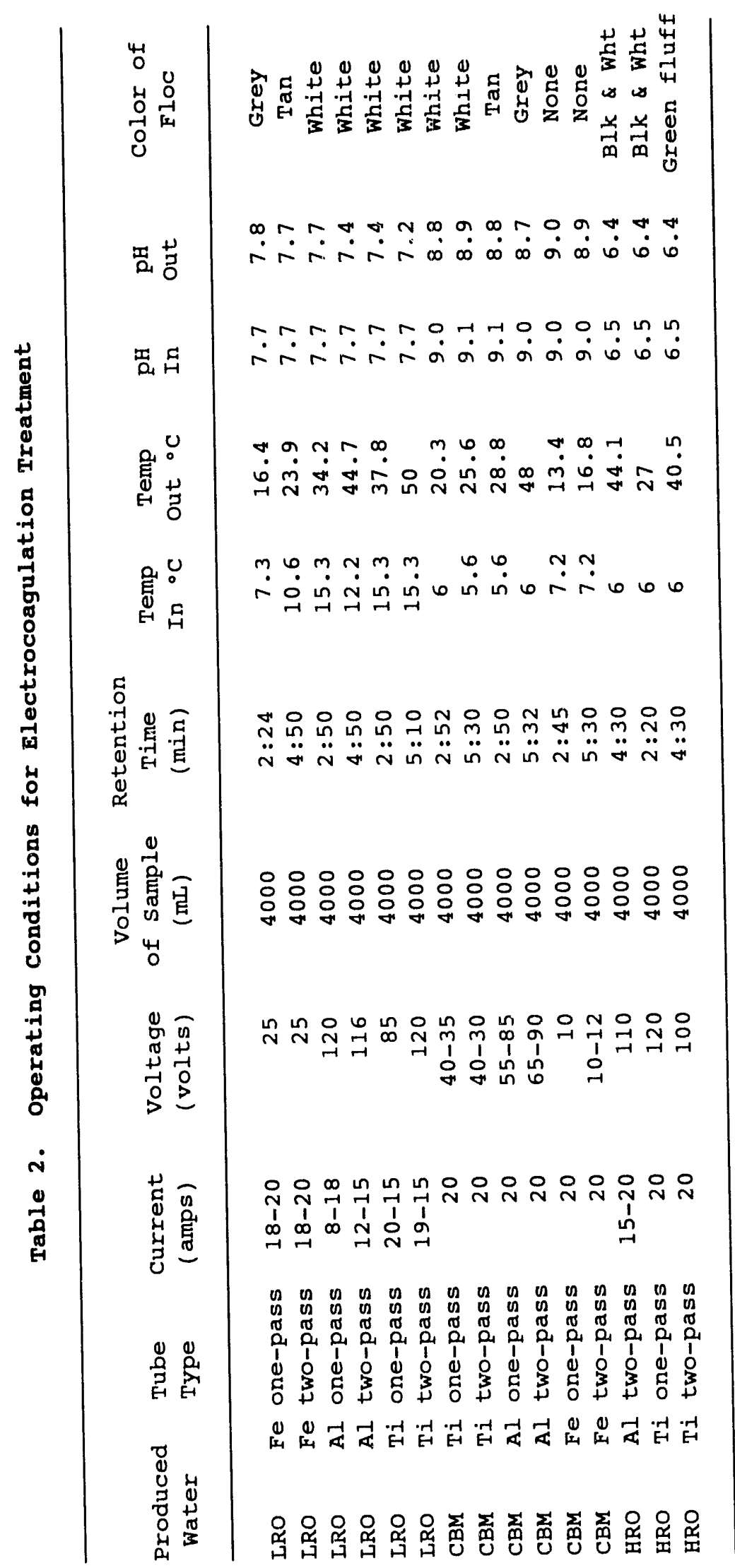


For each Ro run, the concentrate or reject was recycled back to the feedwater container until the whole system reached equilibrium and no more permeate was produced. This method simulates a large Ro production unit that would utilize a series of spirally wound membrane elements (Parekh 1988).

The pump was set to deliver a flow volume of $4 \mathrm{~mL} / \mathrm{s}$. This low flow rate was chosen to minimize the pressure variations over the pump stroke. The feedwater was allowed to reach room temperature $\left(20^{\circ} \mathrm{C}\right)$ before each run. Three liters of feedwater was used in each run. Each of the three membranes was run at two different concentrate outlet pressures, and the pressure applied to the membrane cell plates was maintained at 1000 psig to minimize any movement of the plates due to pressure variations.

After each run the unit was cleaned with hot tap water and then distilled water, and a new cell membrane was installed. The Ro unit was then run with distilled water for a period of approximately 10 minutes to allow the membrane to wet and to clean the system further. The feedwater and permeate containers were glass vessels that had been acid washed to minimize contamination of the sample. The reject or concentrate stream was recycled back to the feedwater container, and both containers were capped with a paraffin film to minimize evaporation during the run. Times were recorded for specific volumes of permeate until the test was concluded. Once the test was concluded, the permeate was stirred and transferred to the appropriate containers for the specific analyses to be performed.

\section{RESULTS AND DISCUSSION}

The characterization of the raw produced waters indicated an array of chemical species and concentrations of those species (Table 3 ). All three produced waters contained substantial amounts of radium 226, total solids, and oil and grease; thus the project objectives that were initially identified could be achieved.

\section{Electrocoagulation}

\section{Removal of Radium 226}

Percent removals of radium 226 by the electrocoagulation treatment process ranged from 24 to near 1008 for all the waters tested. The best removal efficiencies were obtained with the titanium tube, which had a non-sacrificial titanium anode. Electrocoagulation treatment with the titanium tube reduced the radium 226 concentration from $29.2 \mathrm{pc} / \mathrm{L}$ to 0.8 $\mathrm{pc} / \mathrm{L}$ for the low radium oil (LRO) produced water, which corresponded to 97.38 removal. Treatment with the titanium tube reduced the radium 226 concentration in the high radium oil (HRO) produced water from $116 \mathrm{pc} / \mathrm{L}$ to $18.9 \mathrm{pc} / \mathrm{L}$, which corresponded to $83.7 \%$ removal. Treatment with the titanium tube reduced the radium 226 concentration in the coal bed methane (CBM) produced water from $12.4 \mathrm{pc} / \mathrm{L}$ to $0.0 \mathrm{pc} / \mathrm{L}$, which corresponded to a 1008 removal. These removals were obtained with the 
Table 3. Characterization of Untreated Produced Waters (mg/L except as noted)

\begin{tabular}{|c|c|c|c|}
\hline Parameter & $\begin{array}{l}\text { Low Radium oil } \\
\text { Produced Water }\end{array}$ & $\begin{array}{l}\text { High Radium Oil } \\
\text { Produced Water }\end{array}$ & $\begin{array}{l}\text { Coal Bed Methane } \\
\text { Produced Water }\end{array}$ \\
\hline Radium $226(\mathrm{pc} / \mathrm{L})$ & 29.2 & 116 & 12.4 \\
\hline Oil \& Grease & 39 & 29.2 & 2 \\
\hline Alkalinity & 1085 & 310 & 13,525 \\
\hline suspended solids & 180 & 20 & 100 \\
\hline Dissolved Solids & 3540 & 3160 & 23,980 \\
\hline Sulfide & 42 & $>100$ & $<1$ \\
\hline Fluoride & No Test & 4.61 & No Test \\
\hline Chloride & 510 & 160 & 5,960 \\
\hline Nitrite as $\mathrm{N}$ & $<0.004$ & $<0.01$ & $<0.004$ \\
\hline Bromide & 2.41 & $<0.01$ & 3.63 \\
\hline Nitrate as $\mathrm{N}$ & $<0.004$ & $<0.01$ & 0.37 \\
\hline Phosphate as $\mathrm{P}$ & $<0.01$ & $<0.01$ & $<0.01$ \\
\hline sulfate & 1300 & 1620 & 13.5 \\
\hline Mineral Carbon & 72 & 260 & 2800 \\
\hline TOC & No Test & $<10$ & No Test \\
\hline Silver & $<0.007$ & $<0.04$ & $<0$ \\
\hline Aluminum & $<0.05$ & $<0.23$ & $<0.50$ \\
\hline Arsenic & $<0.10$ & $<0.5$ & $<1.0$ \\
\hline Boron & 1.6 & 2.6 & 3.5 \\
\hline Barium & 0.05 & 0.06 & 1.9 \\
\hline Beryllium & $<0.002$ & $<0.01$ & $<0.02$ \\
\hline Bismuth & $<0.10$ & $<0.5$ & $<1.0$ \\
\hline Calcium & 460 & 420 & 9.1 \\
\hline Cadmium & $<0.01$ & $<0.05$ & $<0.1$ \\
\hline Cobalt & $<0.007$ & $<0.04$ & $<0.07$ \\
\hline Chromium & $<0.008$ & 0.04 & 0.08 \\
\hline Copper & $<0.006$ & $<0.03$ & $<0.06$ \\
\hline Iron & $<0.006$ & & 0.38 \\
\hline Mercury & $<0.50$ & & $<5.0$ \\
\hline Potassium & 89 & 68 & 240 \\
\hline Lithium & 1.5 & 0.79 & 5.3 \\
\hline Magnesium & 77 & 79 & 20 \\
\hline Manganese & $<0.003$ & $<0.02$ & $<0.03$ \\
\hline Molybdenum & $<0.01$ & $<0.05$ & $<0.10$ \\
\hline sodium & 450 & 510 & 9000 \\
\hline Nickel & $<0.02$ & $<0.1$ & $<0.2$ \\
\hline Phosphorus & $<1.0$ & $<5$ & $<10$ \\
\hline Lead & 0.05 & $<0.3$ & $<0.5$ \\
\hline Antimony & $<0.10$ & $<0.5$ & $<1.0$ \\
\hline Selenium & $<0.10$ & $<0.5$ & $<1.0$ \\
\hline silicon & 15 & & $<1.0$ \\
\hline strontium & 7.1 & & $<1.0$ \\
\hline Thorium & $<0.05$ & $<0.3$ & $<0.5$ \\
\hline Vanadium & $<0.008$ & $<0.04$ & $<0.08$ \\
\hline $\operatorname{zinc}$ & 0.01 & $<0.02$ & $<0.03$ \\
\hline
\end{tabular}


"two-pass" treatment method, which effectively doubled the retention time in the tubes to 5:30 minutes for the LRO and CBM waters and 4:30 minutes for the HRO. The one-pass treatment with the titanium tube reduced the radium 226 concentration from $29.2 \mathrm{pc} / \mathrm{L}$ to $8.6 \mathrm{pc} / \mathrm{L}$ (70.58 removal) for the LRO, from $12.4 \mathrm{pc} / \mathrm{L}$ to $5.6 \mathrm{pc} / \mathrm{L}$ ( 54.88 removal) for the CBM produced water and from $116 \mathrm{pc} / \mathrm{L}$ to $38.9 \mathrm{pc} / \mathrm{L}$ ( 66.48 removal) for the HRO with retention times of 2:50 minutes, 2:52 minutes, and 2:15 minutes, respectively.

The average radium 226 removals for all three waters with the twopass treatment were 93.78 removal for the titanium tube, 83.38 removal for the aluminum tube, and 42.18 removal for the iron tube. However, the one-pass treatment showed 63.98 radium 226 removal for the titanium tube, $83.4 \%$ radium 226 removal for the aluminum tube, and 99.38 radium 226 removal for the one analysis on the iron tube. A complete analysis on the variations in treatment removals for radium 226 with the given electrocoagulation tube and retention time is difficult without a more comprehensive study of all the produced waters under all the given treatment conditions. Replicated runs should also be performed and analyzed to establish any inherent variability in the process.

The results showed that electrocoagulation treatment effectively removed radium 226. The higher removals of radium 226 by the titanium tube may have been in part due to the chemical reactions associated with an inert anode. The free oxygen radicals that may have been formed at the inert anode of the titanium tube may cause radium 226 particles to form complexes with other particles in solution or become adsorbed onto newly formed complexes and settle out with the precipitates. The oxygen or hydroxide radicals produced at the inert anode may also cause oxidation of organics. The oxidized and un-oxidized organics can also react with ozone and hydrogen peroxide, possibly created at the anode, to prriuce carbon dioxide and water. This reaction would release any radiur 226 adsorbed onto the organics in solution and allow the radium 226 particles to react with other ccimponents in solution or be adsorbed onto the precipitate formed and subsequently settle out with the floc.

A thick floc was created when the aluminum tube was used for treatment. Possibly, the radium 226 was adsorbed onto the floc or the particles that they were associated with could have become entrapped in the settling floc and would thus have been removed from the solution. suspended solids were effectively removed by treatment with the aluminum tube, and the radium 226 species associated with the suspended solids would also be removed. Treatment with the aluminum tube created a similar amount of floc for both the one-pass and two-pass retention times. The corresponding removal of radium 226 for both retention times is nearly the same. The two-pass treatment achieved only 58 more removal for both treatment runs.

The results for the radium 226 removal with the iron tube were inconclusive. Further testing should be done to determine if the onepass treatment is as effective in removing radium 226 as the 99.38 removal ( $29.2 \mathrm{pc} / \mathrm{L}$ to $0.2 \mathrm{pc} / \mathrm{L})$ achieved on the LRO sample indicates. 
Without information from replicate runs and duplicate analysis, this one result did not provide enough information to draw a reasonable conclusion. Tables 4,5 , and 6 summarize the performance achieved using electrocoagulation on the three produced waters.

The radium 226 analysis on the filtered sample of the HRO water is shown in Table 6 . The radium 226 concentration in the filtered sample and the raw HRO sample were $123 \mathrm{pc} / \mathrm{L}$ and $116 \mathrm{pc} / \mathrm{L}$, respectively. The difference in these two values is negligible considering the experimental error inherent in the analysis. The two values do indicate that the amount of radium 226 that was associated with the suspended solids in the sample was small, and that the electrocoagulation process inlist have altered the produced water's dissolved solids physically and shemically.

\section{Oil and Grease Removal}

Electrocoagulation effectively removed oil and grease when the process was operated to create a reasonable amount of floc. The concentration of oil and grease in the LRO was reduced from $39 \mathrm{mg} / \mathrm{L}$ to $<3.0 \mathrm{mg} / \mathrm{L}$ by all three electrocoagulation tubes with the one-pass and two-pass retention times. The concentration of oil and grease in the HRO was reduced from $29.2 \mathrm{mg} / \mathrm{L}$ to $2 \mathrm{mg} / \mathrm{L}$ with the aluminum tube, twopass retention time. However, higher concentrations of oil and grease after treatment for this water indicate that the initial measured concentration was questionable and the removal was probably greater than indicated (see below). Treatment of the HRO with the titanium tube resulted in no reduction of oil and grease. The post-treatment concentrations of $38.9 \mathrm{mg} / \mathrm{L}$ and $31.0 \mathrm{mg} / \mathrm{L}$ for the one-pass and two-pass treatment with the titanium tube indicate that the oil and grease analysis on the raw HRO was probably not accurate and that the concentration of oil and grease in the raw HRo was higher than 29.2 $\mathrm{mg} / \mathrm{L}$. Duplicate samples and duplicate analysis would be required to establish the initial concentration more accurately.

All the electrocoagulation runs that produced a moderate to large amount of floc also greatly reduced the concentration of oil and grease. The two electrocoagulation runs on the HRO with the titanium tube created very little floc and the corresponding removal of oil and grease was minimal to none. All the electrocoagulation runs on the LRo, and the two-pass run with the aluminum tube on the HRO, produced a moderate to large amount of floc. The dissolved oil particles probably adsorbed onto the settling floc and were thus removed from the solution. The emulsified oil (free oil) may have been coagulated if the charged particles released into the solution by the electrocoagulation process reduced the charge density in the emulsion and thus allowed colloidal oil particles to coagulate and settle out of solution. However, the amount of free oil was small in all the samples. Adsorption of dissolved oil particles onto a settling floc and de-emulsification of colloidal free oil has been well studied with chemical and polyelectrolyte coagulation. Studies show that dissolved oil will adsorb to some extent onto floc particles, and the electrically charged particles (positive and negative) in the floc will facilitate the coagulation of emulsified oil particles. 
Table 4. Results of Electrocoagulation Treatment on Low Radium oil Produced water (mg/L except as noted)

\begin{tabular}{|c|c|c|c|c|c|c|c|}
\hline Parameter & $\begin{array}{l}\text { Untreated } \\
\text { Wastewater }\end{array}$ & $\begin{array}{c}\text { Fe } \\
\text { One- } \\
\text { Pass }\end{array}$ & $\begin{array}{c}\text { Fe } \\
\text { Two- } \\
\text { Pass }\end{array}$ & $\begin{array}{c}\text { Al } \\
\text { One- } \\
\text { Pass }\end{array}$ & $\begin{array}{c}\text { Al } \\
\text { Two- } \\
\text { Pass }\end{array}$ & $\begin{array}{c}\mathrm{Ti} \\
\text { One- } \\
\text { Pass }\end{array}$ & $\begin{array}{c}\text { Ti } \\
\text { Two- } \\
\text { Pass }\end{array}$ \\
\hline Radium $226(\mathrm{pc} / \mathrm{L})$ & 29.2 & 0.2 & 11.7 & 7.8 & 6.4 & 8.6 & 0.8 \\
\hline Oil \& Grease & 39 & $<3$ & $<3$ & $<3$ & $<3$ & $<3$ & $<3$ \\
\hline Alkalinity & 1085 & 815 & 672 & 735 & 687 & 715 & 570 \\
\hline suspended solids & 180 & 70 & 90 & 0 & 20 & 10 & 20 \\
\hline Dissolved Solids & 3540 & 3350 & 3060 & 3090 & 2930 & 3150 & 2740 \\
\hline silver & $<0.007$ & $<0.04$ & $<0.04$ & $<0.04$ & $<0.04$ & $<0.04$ & $<0.04$ \\
\hline Aluminum & $<0.05$ & $<0.23$ & $<0.23$ & 0.24 & 1 & $<0.23$ & $<0.23$ \\
\hline Arsenic & $<0.10$ & $<0.50$ & $<0.50$ & $<0.50$ & $<0.50$ & $<0.50$ & $<0.50$ \\
\hline Boron & 1.6 & 1.7 & 1.7 & 1.8 & 2 & 1.6 & 1.7 \\
\hline Barium & 0.05 & $<0.05$ & $<0.05$ & $<0.05$ & $<0.05$ & $<0.05$ & $<0.05$ \\
\hline Beryllium & $<0.002$ & $<0.01$ & $<0.01$ & $<0.01$ & $<0.01$ & $<0.01$ & $<0.01$ \\
\hline Bismuth & $<0.10$ & $<0.50$ & $<0.50$ & $<0.50$ & $<0.50$ & $<0.50$ & $<0.50$ \\
\hline Calcium & 460 & 530 & 450 & 450 & 390 & 450 & 360 \\
\hline Cadmium & $<0.01$ & $<0.05$ & $<0.05$ & $<0.05$ & $<0.05$ & $<0.05$ & $<0.05$ \\
\hline Cobalt & $<0.007$ & $<0.04$ & $<0.04$ & $<0.04$ & $<0.04$ & $<0.04$ & $<0.04$ \\
\hline Chromium & $<0.008$ & $<0.04$ & $<0.04$ & $<0.04$ & $<0.04$ & $<0.04$ & $<0.04$ \\
\hline Copper & $<0.006$ & $<0.03$ & $<0.03$ & $<0.03$ & $<0.03$ & $<0.03$ & $<0.03$ \\
\hline Iron & $<0.006$ & 0.27 & 0.39 & $<0.03$ & $<0.03$ & $<0.03$ & $<0.03$ \\
\hline Mercury & $<0.50$ & $<2.5$ & $<2.5$ & $<2.5$ & $<2.5$ & $<2.5$ & $<2.5$ \\
\hline Potassium & 89 & 180 & 160 & 170 & 160 & 170 & 170 \\
\hline Lithium & 1.5 & 1.7 & 1.6 & 1.5 & 1.6 & 1.6 & 1.5 \\
\hline Magnesium & 77 & 93 & 91 & 87 & 89 & 89 & 88 \\
\hline Manganese & $<0.003$ & $<0.02$ & 0.03 & $<0.02$ & $<0.02$ & $<0.02$ & $<0.02$ \\
\hline Moly' denum & $<0.01$ & $<0.05$ & $<0.05$ & $<0.05$ & $<0.05$ & $<0.05$ & $<0.05$ \\
\hline sodium & 450 & 500 & 490 & 460 & 480 & 480 & 470 \\
\hline Nickel & $<0.02$ & $<0.10$ & $<0.01$ & $<0.01$ & $<0.01$ & $<0.01$ & $<0.01$ \\
\hline Phosphorus & $<1.0$ & $<5.0$ & $<5.0$ & $<5.0$ & $<5.0$ & $<5.0$ & $<5.0$ \\
\hline Lead & 0.05 & $<0.25$ & $<0.25$ & $<0.25$ & $<0.25$ & $<0.25$ & $<0.25$ \\
\hline Antimony & $<0.10$ & $<0.50$ & $<0.50$ & $<0.50$ & $<0.50$ & $<0.50$ & $<0.50$ \\
\hline selenium & $<0.10$ & $<0.50$ & $<0.50$ & $<0.50$ & $<0.50$ & $<0.50$ & $<0.50$ \\
\hline Silicon & 15 & 18 & 17 & 9.9 & 7 & 17 & 14 \\
\hline strontium & 7.1 & 7.2 & 6.5 & 6.1 & 5.6 & 6.5 & 5.4 \\
\hline Thorium & $<0.05$ & $<0.25$ & $<0.25$ & $<0.25$ & $<0.25$ & $<0.25$ & $<0.25$ \\
\hline Vanadium & $<0.008$ & $<0.04$ & $<0.04$ & $<0.04$ & $<0.04$ & $<0.04$ & $<0.04$ \\
\hline Zinc & 0.01 & $<0.02$ & $<0.02$ & $<0.02$ & $<0.02$ & $<0.02$ & $<0.02$ \\
\hline
\end{tabular}

Note: Different detection limits for the same parameter result from dilution of samples required in analysis procedure. 
Table 5. Results of Electrocoagulation Treatment on Coal Bed Methane Produced water (mg/L except as noted)

\begin{tabular}{|c|c|c|c|c|c|c|c|}
\hline Parameter & $\begin{array}{l}\text { Jntreated } \\
\text { astewater }\end{array}$ & $\begin{array}{c}\mathrm{Fe} \\
\text { One- } \\
\text { Pass }\end{array}$ & $\begin{array}{c}\text { Fe } \\
\text { Two- } \\
\text { Pass }\end{array}$ & $\begin{array}{c}\text { Al } \\
\text { One- } \\
\text { Pass }\end{array}$ & $\begin{array}{c}\text { Al } \\
\text { Two- } \\
\text { Pass }\end{array}$ & $\begin{array}{c}\mathrm{Ti} \\
\text { One- } \\
\text { Pass }\end{array}$ & $\begin{array}{c}\text { Ti } \\
\text { Two- } \\
\text { Pass }\end{array}$ \\
\hline Radium 226 (pc/L) & 12.4 & $\mathrm{NT}^{\mathrm{a}}$ & 9.4 & 0.8 & 0.2 & 5.6 & 0 \\
\hline Oil \& Grease & 2 & NT & NT & NT & $\mathrm{NT}$ & $\mathrm{NT}$ & NT \\
\hline Alkalinity & 13,500 & 13,750 & 13,850 & 13,150 & 13,250 & 13,700 & 13,675 \\
\hline Suspended Solids & 90 & 0 & 90 & 50 & 60 & 80 & 75 \\
\hline Dissolved Solids & 23,975 & 24,030 & 23,920 & 24,300 & 23,930 & 24,200 & 24,000 \\
\hline Silver & $<0.07$ & 0.04 & $<0.04$ & $<0.04$ & $<0.04$ & $<0.04$ & $<0.04$ \\
\hline Aluminum & $<0.50$ & $<0.23$ & $<0.23$ & 0.24 & 1 & $<0.23$ & $<0.23$ \\
\hline Arsenic & $<1.0$ & $<0.50$ & $<0.50$ & $<0.50$ & $<0.50$ & $<0.50$ & $<0.50$ \\
\hline Boron & 3.5 & 3.1 & 3 & 3 & 3.1 & 3.3 & 3.2 \\
\hline Barium & 1.9 & 1.6 & 1.5 & 0.21 & 0.17 & 0.21 & 0.08 \\
\hline Beryllium & $<0.02$ & $<0.01$ & $<0.01$ & $<0.01$ & $<0.01$ & $<0.01$ & $<0.01$ \\
\hline Bismuth & $<1.0$ & $<0.50$ & $<0.50$ & $<0.50$ & $<0.50$ & $<0.50$ & $<0.50$ \\
\hline Calcium & 9.1 & 9.3 & 9.5 & 2.7 & 3 & 7.2 & 5.1 \\
\hline Cadmium & $<0.1$ & $<0.05$ & $<0.05$ & $<0.05$ & $<0.05$ & $<0.05$ & $<0.05$ \\
\hline Cobalt & $<0.07$ & $<0.04$ & $<0.04$ & $<0.04$ & $<0.04$ & $<0.04$ & $<0.04$ \\
\hline Chromium & 0.08 & $<0.04$ & 0.05 & $<0.04$ & $<0.04$ & $<0.04$ & $<0.04$ \\
\hline Copper & $<0.06$ & 0.06 & 0.09 & 0.07 & 0.09 & 0.06 & 0.06 \\
\hline Iron & 0.38 & 1.9 & 3.2 & 1.5 & 2.8 & $<0.03$ & $<0.03$ \\
\hline Mercury & $<5.0$ & $<2.5$ & $<2.5$ & $<2.5$ & $<2.5$ & $<2.5$ & $<2.5$ \\
\hline Potassium & 240 & 150 & 160 & 160 & 160 & 180 & 190 \\
\hline Lithium & 5.3 & 5.4 & 5.3 & 5.3 & 5 & 5.7 & 5.7 \\
\hline Magnesium & 20 & 17 & 17 & 15 & 13 & 17 & 16 \\
\hline Manganese & $<0.03$ & 0.04 & 0.05 & 0.03 & 0.03 & $<0.02$ & $<0.02$ \\
\hline Molybdenum & $<0.10$ & $<0.05$ & $<0.05$ & $<0.05$ & $<0.05$ & $<0.05$ & $<0.05$ \\
\hline Sodium & 9000 & 8600 & 8600 & 8600 & 8300 & 9000 & 9300 \\
\hline Nickel & $<0.2$ & $<0.10$ & $<0.01$ & $<0.01$ & $<0.01$ & $<0.01$ & $<0.01$ \\
\hline Phosphorus & $<10$ & $<5.0$ & $<5.0$ & $<5.0$ & $<5.0$ & 7.6 & $<5.0$ \\
\hline Lead & $<0.5$ & $<0.25$ & $<0.25$ & $<0.25$ & $<0.25$ & $<0.25$ & $<0.25$ \\
\hline Antimony & $<1.0$ & $<0.50$ & $<0.50$ & $<0.50$ & $<0.50$ & $<0.50$ & $<0.50$ \\
\hline Selenium & $<1.0$ & $<0.50$ & $<0.50$ & $<0.50$ & $<0.50$ & $<0.50$ & $<0.50$ \\
\hline silicon & $<1.0$ & $<0.50$ & $<0.50$ & $<0.50$ & $<0.50$ & $<0.50$ & $<0.50$ \\
\hline strontium & $<1.0$ & 0.12 & 0.12 & 0.03 & 0.04 & 0.07 & 0.03 \\
\hline Thorium & $<0.5$ & $<0.25$ & 0.26 & 0.29 & 0.27 & 0.31 & 0.26 \\
\hline Vanadium & $<0.08$ & $<0.04$ & 0.05 & 0.06 & 0.07 & 0.07 & 0.05 \\
\hline Zinc & $<0.03$ & 0.06 & 0.04 & $<0.02$ & $<0.02$ & $<0.02$ & $<0.02$ \\
\hline
\end{tabular}

a $\quad \mathrm{NT}=$ not tested

Note: Different detection limits for the same parameter result from dilution of samples required in analysis procedure. 

Table 6. Results of Electrocoagulation Treatment on High Radium oil
Produced Water (mg/L except as noted)

\begin{tabular}{|c|c|c|c|c|c|}
\hline & $\begin{array}{l}\text { Untreated } \\
\text { wastewater }\end{array}$ & $\begin{array}{c}\mathrm{Ti} \\
\text { One-Pass }\end{array}$ & $\begin{array}{c}\text { Ti } \\
\text { Two-pass }\end{array}$ & $\begin{array}{c}\text { Al } \\
\text { Two-pass }\end{array}$ & Filtered \\
\hline Radium $226(\mathrm{pc} / \mathrm{L})$ & 116 & 38.9 & 18.9 & 30.7 & 123 \\
\hline oil \& Grease & 29.2 & 38 & 31 & 2 & \\
\hline Alkalinity & 310 & 260 & 180 & 210 & \\
\hline suspended Solids & 20 & 0 & 0 & 0 & \\
\hline Dissolved Solids & 3160 & 2900 & 2920 & 2560 & \\
\hline silver & $<0.04$ & & $<0.04$ & $<0.04$ & \\
\hline Aluminum & $<0.23$ & & $<0.23$ & 0.34 & \\
\hline Arsenic & $<0.50$ & & $<0.50$ & $<0.50$ & \\
\hline Boron & 2.6 & & 2.5 & 2.6 & \\
\hline Barium & 0.06 & & 0.06 & 0.06 & \\
\hline Beryllium & $<0.01$ & & $<0.01$ & $<0.01$ & \\
\hline Bismuth & $<0.5$ & & $<0.5$ & $<0.5$ & \\
\hline Calcium & 420 & & 380 & 300 & \\
\hline Cadmium & $<0.05$ & & $<0.05$ & $<0.05$ & \\
\hline cobalt & $<0.04$ & & $<0.04$ & $<0.04$ & \\
\hline Chromium & $<0.04$ & & $<0.04$ & $<0.04$ & \\
\hline Copper & $<0.03$ & & $<0.03$ & $<0.03$ & \\
\hline Iron & $\mathrm{NT}^{\mathrm{a}}$ & & $\mathrm{NT}$ & $\mathrm{NT}$ & \\
\hline Mercury & $\mathrm{NT}$ & & NT & $\mathrm{NT}$ & \\
\hline Potassium & 68 & & 64 & 68 & \\
\hline Lithium & 0.79 & & 0.77 & 0.82 & \\
\hline Magnesium & 79 & & 75 & 77 & \\
\hline Manganese & $<0.02$ & & $<0.02$ & $<0.02$ & \\
\hline Molybdenum & $<0.05$ & & $<0.05$ & $<0.05$ & \\
\hline Sodium & 510 & & 480 & 540 & \\
\hline Nickel & $<0.1$ & & $<0.1$ & $<0.1$ & \\
\hline Phosphorus & $<5$ & & $<5$ & $<5$ & \\
\hline Lead & $<0.3$ & & $<0.3$ & $<0.3$ & \\
\hline Antimony & $<0.5$ & & $<0.5$ & $<0.5$ & \\
\hline Selenium & $<0.5$ & & $<0.5$ & $<0.5$ & \\
\hline silicon & $\mathrm{NT}$ & & $\mathrm{NT}$ & $\mathrm{NT}$ & \\
\hline strontium & $\mathrm{NT}$ & & $\mathrm{NT}$ & $\mathrm{NT}$ & \\
\hline Thorium & $<0.3$ & & $<0.3$ & $<0.3$ & \\
\hline Vanadium & $<0.04$ & & $<0.04$ & $<0.04$ & \\
\hline zinc & $<0.02$ & & $<0.02$ & $<0.02$ & \\
\hline sulfide & $>100$ & 190 & 170 & 230 & \\
\hline TOC & $<10$ & $<10$ & $<10$ & $<10$ & \\
\hline Fluoride & 4.61 & 4.93 & 5.02 & 4.15 & \\
\hline Chloride & 160 & 145 & 145 & 127 & \\
\hline Nitrate as $\mathrm{N}$ & $<0.01$ & $<0.01$ & $<0.01$ & $<0.01$ & \\
\hline Bromide & $<0.01$ & $<0.01$ & $<0.01$ & $<0.01$ & \\
\hline Nitrate as $\mathrm{N}$ & $<0.01$ & $<0.01$ & $<0.01$ & $<0.01$ & \\
\hline Phosphate as $\mathrm{P}$ & $<0.01$ & $<0.01$ & $<0.01$ & $<0.01$ & \\
\hline sulfate & 1620 & 1610 & 1650 & 1290 & \\
\hline Mineral Carbon & 72 & 57 & 48 & 44 & \\
\hline
\end{tabular}

a $\quad \mathrm{NT}=$ not tested 
The amount of floc produced by electrocoagulation is probably dependent on many factors: the amount and type of dissolved solids in the solution, the type of electrocoagulation tube, the retention time, and the temperature of the solution. More experimentation would be required to establish what type of floc removed oil and grease more efficiently.

\section{Reverse Osmosis}

\section{Removal of Total Dissolved Solids}

Reverse osmosis removed dissolved and suspended solids from the CBM produced water. The total dissolved solids concentration in the CBM produced water was reduced from $24,000 \mathrm{mg} / \mathrm{L}$ to between 3,100 and 7,560 $\mathrm{mg} / \mathrm{L}$ during treatment with three different membranes, and at various outlet pressures (Table 7). All suspended solids (SS) were removed. A more complete discussion of removal efficiencies achieved with reverse osmosis with different membranes and at various outlet pressures would be appropriate; however, the treatment performances were more dependent on the problems resulting from the piston pump and the corresponding damage to the membranes.

Table 7. Results of Reverse Osmosis Treatment on Coal Bed Methane Produced Water

\begin{tabular}{lcrrr}
\hline $\begin{array}{c}\text { Type of } \\
\text { Membrane }\end{array}$ & $\begin{array}{c}\text { Outlet } \\
\text { pressure } \\
\text { (psig) }\end{array}$ & $\begin{array}{c}\text { Permeate } \\
\text { TDS } \\
\text { (mg/L) }\end{array}$ & $\begin{array}{c}\text { Percent } \\
\text { TDS } \\
\text { Removal }\end{array}$ & $\begin{array}{c}\text { Percent } \\
\text { SS } \\
\text { Removal }\end{array}$ \\
\hline Sepa CF ST10 & 400 & 21,010 & 12.5 & 100 \\
Sepa CF ST10 & 500 & 3,100 & 87.1 & 100 \\
Sepa CF ST10 & 600 & 5,900 & 75.4 & 100 \\
Sepa CF SR10 & 400 & 4,760 & 80.2 & 100 \\
Sepa CF SR10 & 700 & 7,560 & 68.5 & 100 \\
Sepa CF MS10 & 500 & 6,140 & 74.4 & 100 \\
\hline
\end{tabular}

\section{Radium 226 Removal}

Reverse osmosis removed radium 226. The initial radium 226 concentration in the CBM-produced water was $12.4 \mathrm{pc} / \mathrm{L}$. This concentration was lowered to $5.1 \mathrm{pc} / \mathrm{L}$ by the ST10 membrane at 600 psig outlet pressure, to $0.6 \mathrm{pc} / \mathrm{L}$ by the ST10 membrane at 500 psig outlet pressure, to $3.0 \mathrm{pc} / \mathrm{L}$ by the SR10 membrane at 400 psig outlet pressure, to $1.0 \mathrm{pc} / \mathrm{L}$ by the SR10 membrane at $700 \mathrm{psig}$ outlet pressure, and to 1.2 pc/L by the MS10 membrane at 500 psig outlet pressure. Radium 226 particles that were associated with colloidal particles or dissolved solids in the solution were probably rejected by the membrane because of the size of the particles. 
There were several problems with the Ro equipment that made the results questionable. The problems were created by the piston pump. The pump would cause a pressure surge and drop in the Ro unit for each pump stroke. The dampening system that was used did not completely dampen out the pressure variations. Since the pressure across the membrane was not constant, the permeate flow was a function of a pressure range and not one specific pressure. Another problem created by the pump was that the plates that held the Ro membrane in place would move slightly with each pressure variation, thus causing the membrane to wear at the site of contact with the rubber o-ring. The worn areas of the membrane could then allow preferential flow through to the permeate stream. The worn areas of the membrane would not reject dissolved solids as effectively as the intact membrane surface and a higher percentage of solids would flow through to the permeate outlet as a result.

However, the results do show that the CBM produced water could be treated effectively with Ro to reduce dissolved and suspended solids concentrations, thus concurrently lowering the concentrations of components such as radium 226. Reverse osmosis would be a treatment alternative for this water depending on its intended use, but the cost of using the Ro process at pressures above $500 \mathrm{psig}$ would have to be taken into consideration. The disposal of the brine created in the Ro prcaess may also be an economic consideration.

\section{CONCLUSIONS}

1. The best treatment with electrocoagulation reduced the radium 226 concentration from $29.2 \mathrm{pc} / \mathrm{L}$ to $0.2 \mathrm{pc} / \mathrm{L}$ and the oil and grease concentration from $39 \mathrm{mg} / \mathrm{L}$ to less than $3 \mathrm{mg} / \mathrm{L}$ in the oil produced water.

2. The best removal of radium 226 was achieved with the titanium electrocoagulation tube, while the best removal of oil and grease was achieved with the aluminum electrocoagulation tube.

3. Radium 226 and oil and grease concentrations were lowered in the two oil produced waters to below the current WDEQ discharge standards.

4. Treatment with reverse osmosis reduced the total dissolved solids concentration in the coal bed methane produced water from 24,000 $\mathrm{mg} / \mathrm{L}$ to $3,100 \mathrm{mg} / \mathrm{L}$ along with all suspended solids.

5. Treatment of the coal bed methane produced water with reverse osmosis reduced the radium 226 concentration from $12.4 \mathrm{pc} / \mathrm{L}$ to 0.6 pc/I using an ST10 membrane at 500 psig. 


\section{ACKNOWLEDGMENTS}

We would like to thank the Wyoming Oil and Gas Commission in Casper and the Wyoming Department of Environmental quality in Cheyenne for their expert advice on produced waters in the state of wyoming. We would also like to thank the oil and gas producers who allowed us to take samples. support for this work was provided by the U.S. Department of Energy under Cooperative Agreement DE-FC21-86MC11076.

\section{DISCLAIMER}

Mention of specific brand names or models of equipment is for information only and does not imply endorsement of any particular brand. 


\section{REFERENCES}

Cox, Bruce A., 1989, Wyoming whole Effluent roxj.city program for Produced Water, Marathon oil Company, Littleton, Co.

Eckenfelder, W.W., 1989, Industrial Water Follution Control, McGrawHill, New York, NY.

Herbst, R.J., and Russell R. Renk, 1987, Application for U.S. Patent, Application Serial No. 074,680.

Parekh, B.S., 1988, Reverse Osmosis Technology, Marcel Decker, New York, NY.

Renk, R.R., 1988, Electrocoagulation of Tar Sand and oil ihale Wastewaters, Energy Process, 8(4) 205-208.

Thortec International, 1988, Engineering Validation and Technology Development for Electroprecipitation Electrocoagulation of $f$ red by CURE, internal document, URS Consultants, san Mateo, CA.

U.S. Department of the Interior Bureau of Land Management, 1990, Coal Bed Methane Environmental Assessment, Eastern Campbell and Western Johnson Counties, Wyoming, U.S. B.L.M., Casper, WY.

Wyoming Department of Environmental quality, 1984, water quality Rules and Regulations, Chapter I. 

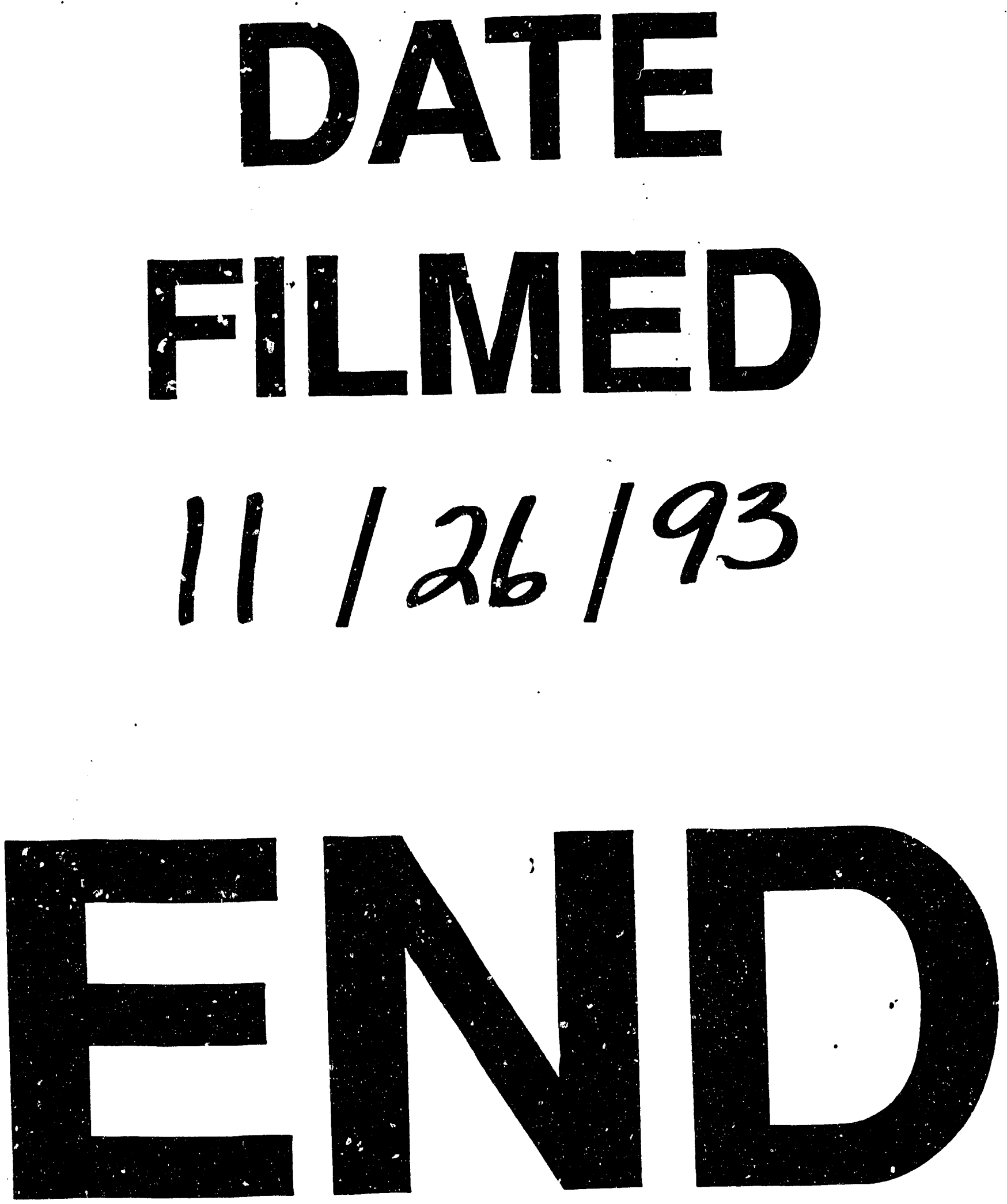
